\title{
LIMA MENIT KEGIATAN PENDAHULUAN YANG BERMAKNA (KAJIAN MOTIVASI)
}

\author{
Maria W. Lidi ${ }^{1, a)}$ dan Ningsih ${ }^{2, b)}$ \\ ${ }^{1,2)}$ Dosen Program Studi Pendidikan Matematika, Fakultas Keguruan dan Ilmu \\ Pendidikan, Universitas Flores
}

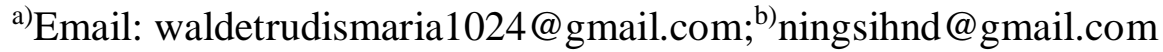

\begin{abstract}
Abstrak.Telah dilakukan suatu penelitian melalui telaah pustaka tentang kajian motivasi pada standar proses pembelajaran khususnya pada kegiatan pendahuluan. Berdasarkan temuan awal peneliti, umumnya kegiatan pendahuluan yang terjadi menyimpang dari acuan yang diberikan pemerintah dalam permen 22 tahun 2016. Pada Permen 22 tentang standar proses pendidikan dasar dan menengah tertuang bahwa pada kegiatan pendahuluan guru wajib menyampaikan tujuan pembelajaran, apersepsi dan motivasi. Akan tetapi ditemukan bahwa dalam pelaksanaan terjadi penyimpangan. Guru merasa kesulitan menerapkan kegiatan motivasi yang dimaksudkan pemerintah karena keterbatasan dalam memahami maksud dari permen 22 tahun 2016. Oleh karena itu penulis merasa penting untuk melakukan kajian tentang kegiatan motivasi pada awal pembelajaran. Selaras dengan tujuan pemerintah, penelitian ini memberikan saran operasional bagaimana meningkatkan motivasi belajar siswa.
\end{abstract}

Kata Kunci:Kegiatan pendahuluan, Motivasi.

\section{PENDAHULUAN}

Untuk apa saya belajar?, pertanyaan sederhana ini menjadi suatu permasalahan ketika peserta didik tidak mendapatkan jawaban yang ia inginkan. Ketidakpuasan yang diperolehnya berdampak pada hasil belajar yang diperolehnya. Tidak dipungkiri kualitas dan keberhasilan suatu proses pembelajaran sangat ditentukan oleh beberapa komponen pendukung yang digunakan guru dalam proses pembelajaran. Ketepatan dalam perencanaan, pelaksanaan dan evaluasi yang dilakukan oleh guru akan dapat membangkitkan motivasi, meningkatkan minat siswa terhadap materi pelajaran yang 
diberikan, yang pada akhirnya meningkatkan kualitas pembelajaran. Perlu disadari sepenuhnya sebaik apapun perencanaan pembelajaran dibuat,jika pelaksanaan proses pembelajaran tidak sesuai dengan perencanaan maka besar kemungkinan untuk gagal.

Pelaksanaan pembelajaran memegang peranan penting dalam keberhasilan suatu proses pembelajaran. Jika pelaksanaan pembelajaran dilakukan asal-asalan maka proses pembelajaran menjadi kurang menarik, membosankan, tidak merangsang siswa untuk aktif dan kreatif, sehingga tujuan pun tidak tercapai. Salah satu aspek penting dalam pelaksanaan pembelajaran adalah pada kegiatan pendahuluan pembelajaran.

Temuan yang diperoleh pada kegiatan observasi pada 1) beberapa sekolah di Kabupaten Ende selama kegiatan Praktek Pengalaman Lapangan; 2) Kegiatan pembelajaran di Universitas Flores; 3) RPP/RPS di sekolah SMP dan SMA dan Perguruan Tinggi, umumnya kegiatan pendahuluan pembelajaran yang terjadi selama ini masih menyimpang dari yang seharusnya dilakukan, di mana pada awal pembelajaran guru cenderung mengajar tanpa adanya pemberian motivasi. Pada kegiatan pendahuluan, guru langsung masuk pada inti atau pokok pembelajaran. Hal ini terjadi karena kegiatan pendahuluan sering disalah artikan sebagai kegiatan untuk mengecek kehadiran siswa atau sekedar salam pembuka sehingga inti yang sebenarnya dari kegiatan pendahuluan diabaikan. Sesuai Permen 22 tahun 2016 tentang standar proses pendidikan dasar dan menengah dijelaskan bahwa pada kegiatan pendahuluan guru wajib memberikan motivasi belajar peserta didik secara kontekstual sesuai manfaat dan aplikasi materi ajar dalam kehidupan sehari-hari (Permen 22 tahun 2016).

Kegiatan pendahuluan sebenarnya adalah langkah awal pemberian motivasi ekstrinsik yang dapat membangkitkan minat belajar siswa (Nur, 2008). Kegiatan ini mengantar siswa atau menarik siswa agar masuk dalam kegiatan pembelajaran dengan cara mengaitkan masalah kehidupan atau pengalaman nyata siswa dengan materi yang akan diajarkan, sehingga siswa dengan sendirinya akan tertarik untuk masuk dalam kegiatan pembelajaran selanjutnya. Pelajaran akan bermakna bagi siswa jika guru berusaha menghubungkannya dengan pengalaman masa lampau, atau pengalaman yang telah mereka miliki sebelumnya. Cara itu berdasarkan pada asumsi bahwa apa yang telah mereka miliki sebagai pengalaman akan merangsang motivasinya untuk mempelajari masalah tersebut lebih lanjut (Permen 22 tahun 2016; Hamalik, 2010).

Berdasarkan permasalahan di atas, penulis merasa penting untuk dilakukannya kajian ilmiah lebih lanjut tentang pemberian motivasi ekstrinsik pada kegiatan pendahuluan yang membangkitkan minat bahkan diharapkan dapat mempertahankan minat belajar karena motivasi ekstrinsik yang kontekstual pada kegiatan pendahuluanmerupakankegiatan lima menit yang menentukan keberhasilan suatu proses pembelajaran.

Penelitian ini menggunakan pendekatan deskriptif kualitatif dan jenis penelitiannya adalah kepustakaan yaitu pengumpulan data yang bersifat kepustakaan atau telaah yang dilaksanakan untuk memecahkan suatu masalah yang bertumpu pada penelaahan kritis dan mendalam terhadap bahan-bahan pustaka yang relevan.

\section{LANDASAN TEORI}

PROSIDING SEMINAR NASIONAL PENDIDIKAN MATEMATIKA ( SENPIKA)

PROGRAM STUDI PENDIDIKAN MATEMATIKA FAKULTAS KEGURUAN DAN ILMU PENDIDIKAN UNIVERSITAS FLORES. ENDE 24 MARET 2018 


\subsection{Motivasi Belajar dan Prinsip-Prinsip Motivasi}

Menurut Slavin (2009), motivasi adalah proses internal yang mengaktifkan, menuntun, dan mempertahankan perilaku dari waktu ke waktu. Lebih lanjut, Mc.Donald (dalam Sardiman, 2010), menyatakan bahwa motivasi adalah perubahan energi dalam diri seseorang yang ditandai dengan munculnya "feeling"dan didahului dengan tanggapan terhadap adanya tujuan. Motivasi akan menyebabkan terjadinya suatu perubahan energi yang ada pada diri manusia, sehingga akan bergayut dengan persoalan gejala kejiwaan, perasaan dan juga emosi, untuk kemudian bertindak atau melakukan sesuatu. Semua ini didorong karena adanya tujuan, kebutuhan atau keinginan.Darkasyi, Johar, Ahmad (2014), menyatakan bahwa berdasarkan teori behaviorisme motivasi sebagai fungsi rangsangan dan respons, dari segi teori kognitif, motivasi adalah fungsi dinamika psikologis yang melibatkan kerangka pikir siswa terhadap berbagai aspek perilaku. yaitu:

Ada beberapa prinsip motivasi dalam belajar (Hakim, 2009; Hamalik, 2010),

a. Motivasi akan meningkat jika materi pembelajaran yang dipelajarinya bermakna karena sesuai dengan bakat, minat, dan pengetahuan dirinya.

b. Pengetahuan, sikap, dan keterampilan yang telah dikuasai siswa dapat menjadi prasyarat untuk penguasaan kompetensi lanjutan.

c. Motivasi belajar akan meningkat jika guru mampu menjadi model bagi siswa untuk ditirunya.

d. Materi atau kegiatan pembelajaran hendaknya bervariasi.

e. Siswa diberi kesempatan mengemukakan pendapatnya dalam situasi pembelajaran yang menyenangkan.

f. motivasi belajar akan meningkat bila pengajaran berhubungan dengan masa depan siswa.

g. Latihan/praktek yang aktif dan bermanfaat.

h. Latihan berbagi; siswa akan lebih senang belajar jika latihan dibagi-bagi menjadi sejumlah kurun waktu yang pendek.

i. Kurangi secara sistematik paksaan belajar.

\subsection{Teori-teori Motivasi}

Teori-teori motivasi yang dikemukan oleh Nur (2008) dan Slavin (2009), menjelaskan tentang mengapa orang termotivasi untuk melakukan sesuatu. Beberapa teori motivasi tersebut dijabarkan sebagai berikut.

Dalam teori perilaku, motivasi merupakan suatu konsekuensi dari penguatan. Nilai suatu penguat bergantung pada banyak faktor, dan kuatnya motivasi dapat berbeda pada setiap individu. Perilaku yang memperoleh penguatan dimasa lalu lebih dimungkinkan untuk diulang daripada perilaku yang tidak memperoleh penguatan atau yang terkena hukuman.

PROSIDING SEMINAR NASIONAL PENDIDIKAN MATEMATIKA ( SENPIKA)

PROGRAM STUDI PENDIDIKAN MATEMATIKA FAKULTAS KEGURUAN DAN 
Berdasarkan teori Maslow, manusia akan memenuhi kebutuhan dasar terlebih dahulu sebelum mereka termotivasi untuk memenuhi kebutuhan-kebutuhan yang tingkatannya lebih tinggi. Semakin orang dapat memenuhi kebutuhan mereka untuk mengenal dan memahami dunia, maka motivasi belajar akan semakin besar.

Menurut Teori disonan kognitif yang dikemukakan oleh Festinger, orang akan mengalami ketegangan atau ketidaknyamanan apabila salah satu dari keyakinan mendalam mereka tertantang oleh sejumlah keyakinan atau perilaku yang tidak konsisten. Ketika mereka mendapatkan hasil yang kurang baik dari kerja mereka, mereka akan memberikan alasan bahwa hasil yang kurang baik disebabkan oleh nasib yang kurang mujur atau alasan-alasan lain untuk menutupi perilaku yang tidak konsisten tersebut.

Teori Atribusi berupaya untuk memahami penjelasan orang atas keberhasilan dan kegagalan mereka. Asumsi utama yang dianut adalah orang akan cenderung mempertahankan gambaran diri yang positif, misalnya ketika terjadi hal-hal yang baik maka mereka akan menghubungkan dengan kemampuan mereka, sebaliknya jika terjadi hal-hal negatif maka orang akan menghubungkannya dengan faktor-faktor di luar kendali mereka.

Teori harapan menyatakan bahwa motivasi seseorang untuk mencapai sesuatu bergantung kepada hasil kali antara estimasi seseorang terhadap peluangnya untuk berhasil dan nilai yang ia berikan pada keberhasilan itu. Motivasi seharusnya maksimum pada tingkat peluang berhasil yang moderat. Aplikasi dalam penyelenggaraan pendidikan adalah suatu tugas yang diberikan hendaknya jangan terlalu mudah atau terlalu sukar.

\section{METODE KAJIAN}

Penelitian ini menggunakan pendekatan deskriptif kualitatif dan jenis penelitiannya adalah kepustakaan yang menelaah secara kritis dan mendalam terhadap bahan-bahan pustaka yang relevan. Penelitian ini dilaksanakan dengan tahap-tahap sebagai berikut.

1) Menentukan masalah penelitian

2) Pengumpulan data, pada tahap ini peneliti menentukan sumber data berupa buku-buku sumber dan teknik pengumpulan data di mana teknik yang digunakan adalah teknik dokumentasi.

3) Analisis dan penyajian data, yaitu menganalisis data untuk ditarik kesimpulan.

Sumber data dalam penelitian ini ada dua yakni 1) sumber data primer, yaitu hasil-hasil penelitian atau tulisan-tulisan karya peneliti atau teoritis yang orisinil; 2) Sumber data sekunder yang merupakan bahan pustaka yang ditulis dan dipublikasikan oleh seorang penulis. Dengan kata lain penulis tersebut bukan penemu teori.

Penelitian ini termasuk penelitian kepustakaan. Oleh karena itu teknik yang digunakan dalam pengumpulan data menggunakan metode dokumentasi yaitu mengumpulkan bahan-bahan pustaka yang koheren dengan objek pembahasan yang

PROSIDING SEMINAR NASIONAL PENDIDIKAN MATEMATIKA ( SENPIKA)

PROGRAM STUDI PENDIDIKAN MATEMATIKA FAKULTAS KEGURUAN DAN 
dimaksud. Data yang ada dalam kepustakaan tersebut dikumpulkan dan diolah dengan cara:

1) Editing yaitu pemeriksaan kembali data yang diperoleh terutama dari segi kelengkapan, kejelasan makna, dan kejelasan makna antara yang satu dengan yang lain.

2) Organizing, mengorganisir data-data yang diperoleh dengan kerangka yang sudah diperlukan.

3) Penemuan hasil penelitian yaitu melakukan analisis lanjutan terhadap hasil pengorganisasian data dengan menggunakan kaidah-kaidah, teori, dan metode yang telah ditentukan sehingga diperoleh kesimpulan tertentu yang merupakan hasil jawaban dari rumusan masalah.

Pada penelitian ini, peneliti memberikan gambaran secara menyeluruh tentang penerapan motivasi pada kegiatan pembelajaran terlebih khusus pada kegiatan pendahuluan. Gambaran hasil kajian ini selanjutnya dikaji dan disimpulkan sesuai dengan tujuan penelitian.

Dalam mengecek keabsahan data peneliti menggunakan teknik ketekunan pengamatan dan mendiskusikan dengan orang lain. Pada teknik ketekunan pengamatan, peneliti menelaah kembali data-data dari sumber data dan keterkaitannya dengan tujuan penelitian. Sedangkan, pada metode kedua, peneliti mendiskusikan kembali data-data dengan orang yang memiliki kompetensi dalam bidang pendidikan yakni teman sejawat (dosen).

\section{HASIL DAN PEMBAHASAN}

4.1. Kedudukan Motivasi Dalam Kegiatan Pembelajaran

Motivasi mempunyai peranan yang sangat penting dalam proses pembelajaran yang mana motivasidapat mengembangkan aktivitas dan inisiatif serta memelihara ketekunan dalam kegiatan pembelajaran. Pemberian motivasi ekstrinsik merupakan tanggung jawab guru dalam rangka membangkitkan motivasi intrinsik. Motivasi ekstrinsik dapat diberikan selama kegiatan pembelajaran berlangsung dan di luar kegiatan pembelajaran. Pemberian motivasi ekstrinsik dalam kegiatan pembelajaran dapat dilakukan baik pada kegiatan pendahuluan, kegiatan inti maupun kegiatan penutup.

1) Kegiatan Pendahuluan

Dewasa ini beberapa ahli pendidikan telah menyadari pentingnya pemberian motivasi ekstrinsik pada kegiatan pembelajaran. Hal ini dapat dilihat pada kerangka Rencana Pelaksanaan Pembelajaran (RPP) yang kian berkembang saat ini, dimana peranan motivasi (ekstrinsik) mulai ditunjukkan dengan memasukkannya pada bagian pendahuluan pembelajaran.

Menurut Slavin (2009), "tugas pendidik bukan meningkatkan motivasi itu sendiri, tetapi menemukan, menggugah, dan mempertahankan motivasi siswa untuk belajar, dan terlibat dalam aktivitas yang menuju pada pembelajaran".Lebih lanjut dikatakan bahwacara yang dapat dilakukan guru untuk meningkatkan motivasi belajar siswa adalah membangkitkan minat.

PROSIDING SEMINAR NASIONAL PENDIDIKAN MATEMATIKA ( SENPIKA)

PROGRAM STUDI PENDIDIKAN MATEMATIKA FAKULTAS KEGURUAN DAN 
Penting untuk membangkitkan minat siswa dengan meyakinkankan siswa akan penting, manfaat dan menariknya materi yang akan mereka pelajari. Sebagai misal pemberian motivasi ekstrinsik dari guru untuk mempelajari materi tentang skala.Guru dapat membuka pelajaran seperti berikut: anak-anak hari ini kita akan dapat mengetahui jarak sebenarnya antara kota A dan B hanya dengan melihat sebuah Peta. Memahami skala itu penting karena banyak digunakan dalam kehidupan kita sehari-hari. Contoh lain: Anak-anak hari ini kita akan dapat mengetahui berapa besar peluang kita menderita penyakit keturunan yang terdapat dalam gen keluarga kita hanya dengan menggunakan rumus matematis sederhana.

Pemberian motivasi akan lebih menarik lagi apabila membuka pelajaran dengan contoh-contoh yang mengaitkan materi pelajaran dengan latar belakang budaya siswa. Membangkitkan rasa ingin tahu tentang pelajaran yang akan diterima akan meningkatkan motivasi instrinsik untuk mempelajari materi tersebut.

Senada dengan Nur, Amri (2013), menyatakan bahwa kategori kondisi yang perlu diperhatikan oleh guru dalam menciptakan pembelajaran bermakna adalah 1) Attention (perhatian); perhatian muncul karena di dorong oleh rasa ingin tahu, oleh karena itu rasa ingin tahu perlu mendapat rangsangan sehingga siswa selalu memberikan perhatian terhadap materi pelajaran yang diberikan. 2) relevance (relevansi), menunjukkan adanya hubungan antara materi pelajaran dengan kebutuhan dan kondisi siswa.

Aritonang (2008), berdasarkan hasil penelitiannya menyimpulkan bahwa berdasarkan analisis angket mengapa siswa mempunyai minat belajar pada mata pelajaran tertentu diketahui bahwa cara mengajar guru yang mendorong rasa ingin tahu siswa dengan hal-hal yang baru, aneh, berbeda dengan yang sebelumnya, kontadiktif, pelajaran menarik dan berguna dalam kehidupan berdampak meningkatkan minat dan motivasi siswa.

Membangkitkan rasa ingin tahu dengan memberikan motivasi ektrinsik pada kegiatan pendahuluan sangatlah penting karena pelajaran akan dirasakan bermakna bagi diri siswa apabila pelajaran itu dapat dikaitkan dengan kehidupan sehari-hari siswa di luar kelas. Hasil penelitian Hamdu dan Agustina (2011), pada kelas 4 sekolah dasar membuktikan bahwa motivasi memberikan pengaruh sebesar $48,1 \%$ pada peningkatan prestasi IPA.

Bila siswa telah menyadari kemungkinan aplikasi pelajaran tersebut maka sudah tentu motivasi belajar akan tergugah dan merangsang kegiatan belajar lebih efektif. Biasanya proses ini terjadi di awal kegiatan pendahuluan pembelajaran.

Pada kegiatan pendahuluan guru perlu mempersiapkan siswa terlebih dahulu sebelum mengikuti pembelajaran. Sesuai teori Maslow tentang pemenuhan kebutuhan manusia, beberapa kebutuhan dasar harus dipenuhi terlebih dahulu sebelum kebutuhan lainnya. Kebutuhan dasar manusia adalah makanan, rasa aman, cinta, dan pemeliharaan harga diri positif. 
Pembelajaran yang menarik tidak akan berarti apabila siswa merasa lapar, sakit atau dilanda rasa takut. Oleh karena itu pada kegiatan pendahuluan guru perlu 1) menanyakan kabar siswa untuk mengecek kondisi fisik atau kesehatan siswa; 2) mengecek siswa yang sudah atau belum sarapan pagi atau makan siang (bagi siswa susah makan/belum makan hendaknya guru perlu memperhatikan tindak lanjutnya melalui program sekolah atau program kelas); 3) Menanamkan gambaran diri positif tentang siswa, misalnya dengan menyampaikan bahwa pada materi yang akan kita pelajari, Ibu/Bapak yakin bahwa kalian dapat menyelesaikan tugas-tugas tersebut dengan baik karena kalian adalah anak-anak yang dapat diandalkan; 4) Menunjukkan rasa cinta dan kasih sayang pada siswa, dengan selalu tersenyum, ramah, menguasai namanama peserta didik, tidak menertawakan atau menghukum suatu kekeliruan yang dibuat oleh siswa.

Kegiatan pedahuluan tidak terlepas dari kegiatan pembelajaran lainnya, oleh karena itu penulis merasa penting untuk sedikit mengkaji motivasi ekstrinsik untuk meningkatkan minat pada kegiatan inti dan penutup.

2) Kegiatan Inti

Tugas guru dalam membangkitkan dan meningkatkan minat siswa tidak berakhir pada kegiatan pendahuluan saja. Tugas selanjutnya adalah bagaimana guru tetap mempertahankan rasa ingin tahu yang telah dibangkitkan pada kegiatan pendahuluan.

Menurut Nur (2008), karena motivasi merupakan suatu sifat pribadi dan dapat timbul dari karakteristik-karakteristik instrinsik suatu tugas maka dengan membuat pelajaran menarik, aktif, terbuka kesempatan berperan serta, maka guru telah membuat siswa semangat belajar. Pada kegiatan inti, mempertahankan rasa ingin tahu guna meningkatkan motivasi pada diri siswa dapat juga dengan 1) menggunakan berbagai macam model presentasi yang menarik, misalnya menggunakan film, video, permainan demonstrasi, pembicara tamu;2) membantu siswa menetapkan tujuan mereka sendiri, prinsip mendasar dari motivasi adalah bahwa orang akan bekerja lebih keras untuk tujuan-tujuan yang mereka tetapkan sendiri daripada tujuan-tujuan yang diperuntukkan bagi mereka namun ditetapkan oleh orang lain (Nur, 2008; Slavin, 2009).

3) Kegiatan Penutup

Guru perlu mempertahankan motivasi siswa dengan memberikan tugas-tugas belajar yang menantang. Hal tersebut sesuai dengan teori disonan kognitif yang dikemukakan oleh Festinger tahun 1957, yakni kebutuhan untuk mempertahankan gambaran diri positif merupakan suatu motivator yang kuat (Slavin, 2009). Ketika diberikan tugas belajar siswa cenderung berusaha mempertahankan gambaran positifnya dengan mengerjakan tugasnya sebaik mungkin, contoh: apabila seseorang yakin bahwa ia cerdas dan bertanggungjawab, ia akan berperilaku memuaskan diri sendiri bahwa ia cerdas dan bertanggungjawab dalam mencapai suatu hasil kerja walaupun tidak ada yang melihat atau melihat, tidak memuji atau memuji.

PROSIDING SEMINAR NASIONAL PENDIDIKAN MATEMATIKA ( SENPIKA) 
Aritonang (2008), menyatakan bahwa guru harus menutup pelajaran dengan hal yang berkesan. Hal ini perlu dilakukan agar materi yang telah dipelajari akan selalu diingat dan siswa akan terus mempelajarinya. Hal-hal yang perlu diperhatikan adalah 1) sediakan tiga atau lima menit untuk menutup pembelajaran; 2) tekankan pada siswa untuk hening guna mengendapkan informasi yang baru diterima; 3) meminta siswa untuk menulis rangkuman singkat; 4) meminta siswa untuk membuat rangkuman lisan; 5) kaitkan kegiatan penutup dengan kegiatan pendahuluan, misalnya kita memulai hari ini dengan...dan kita mempelajari bahwa....

\section{KESIMPULAN}

\subsection{Simpulan}

Kegiatan pendahuluan harusnya dimulai dengan kegiatan yang bermakna, membuka pelajaran dengan sebuah kejutan dan rasa ingin tahu perlu diberikan oleh guru sebagai bentuk motivasi yang dapat meningkatkan ketertarikan siswa pada materi yang selanjutnya berefek pada peningkatan hasil belajar.

\subsection{Saran}

Berdasarkan uraian pembahasan dan kesimpulan di atas, maka penulis menyarankan untuk para guru dari tingkat dasar, menengah dan perguruan tinggi agar kegiatan pendahuluan perlu diawali dengan pemberian motivasi ekstrinsik yang sesuai dengan budaya siswa. Guru perlu menemukan dan mempertahankan motivasi pada diri siswa melalui penjelasan akan manfaat dari materi yang akan mereka pelajari dalam kehidupan siswa.

\section{DAFTAR PUSTAKA}

Amri, S. 2013. Pengembangan dan Model Pembelajaran dalam kurikulum 2013. Jakarta: Pretasi Pustaka.

Aritonang, K. 2008. "Minat dan motivasi dalam meingkatkan Hasil Belajar Siswa". Jurnal Pendidikan Penabur. No. 10/Tahun ke-7/Juni 2008.

Darkasyi, Johar, Ahmad. 2014. "Peningkatan Kemampuan Komunikasi Matematis dan Motivasi Siswa Dengan Pembelajaran Pendekatan Quantum Learning Pada Siswa SMP Negeri 5 Lhokseumawe". Jurnal Didaktik Matematika. Vol. 1, No 1, April 2014.

Hamdu dan Agustina. 2011. "Pengaruh Motivasi Belajar Siswa Terhadap Prestasi Belajar Di Sekolah dasar”. Jurnal Penelitian Pendidikan. Vol. 12, No 1, April 2011.

Hakim, L.2009.Perencanaan Pembelajaran. Bandung : CV.Wacana Prima.

Hamalik, O.2010. Perencanaan Pengajaran Berdasarkan Pendekatan Sistem. Jakarta: Bumi Aksara.

PROSIDING SEMINAR NASIONAL PENDIDIKAN MATEMATIKA ( SENPIKA)

PROGRAM STUDI PENDIDIKAN MATEMATIKA FAKULTAS KEGURUAN DAN ILMU PENDIDIKAN UNIVERSITAS FLORES. ENDE 24 MARET 2018 
Nur, M. 2008. Pemotivasian Siswa Untuk Belajar. Surabaya: UNESA

Permendikbud No 22 tahun 2016 Tentang Standar Proses Pendidikan Dasar dan Menengah (diakses di websitependidikan.com Tanggal 24 Januari 2018).

Sardiman, A.M.. 2010.Interaksi dan motivasi belajar mengajar. Jakarta :Rajawali pers.

Slavin, E. R. 2009.Educational Psychology: Theory and Practice, 9th ed.Terjemahan Samosir, M (2011). Jakarta: PT.Indeks Permata Puri Media. 